УДК 7.034(410.1)8

ББК 85.03

DOI:10.18688/aa155-7-72

Anna Maria Ambrosini Massari

\title{
Johann Zoffany, Classical Art, Italy and Russian Patronage: Shedding New Light on Models, Men and Paintings
}

Antiquity was the great theme in European art and culture in the second half of the $18^{\text {th }}$ century.

Johann Zoffany's (1733-1810) famous painting of the Tribuna of the Uffizi (Royal Collections, UK, Ill. 112) made in Florence between 1772 and 1777, does not portray that room as it was, but sums up a number of classical models of paramount importance in the artistic and social education of any well-bred eighteenth-century European.

The astonishing concentration of masterpieces in the Tribuna was a sum of the ideas of beauty selected from antiquity and the Renaissance, even if, considering the first, Rome was undoubtedly the place to go to discover and experience the antique in eighteenth-century Europe.

Zoffany himself had discovered classical heritage while living in Rome, from 1750 to 1757 and being a pupil of Anton Raphael Mengs who was, together with Johann Joachim Winckelmann, the main testimonial of antiquity's values and models.

It was in Rome that Zoffany approached the composite community of Grand Tourists who probably showed him how much England was becoming the center of modern Europe and contributed to his decision to move there $[8, \mathrm{p} .18]^{1}$.

Zoffany's Classical education is very well shown by a painting he executed in 1753 - in Rome, or perhaps the reason for a short return to Germany - I'm pointing to the Martyrdom of Saint Bartholomew (Regensburg, Museen der Stadt) [14, p. 19] ${ }^{2}$.

The subject and style have various sources: German expressionistic accentuation is reflected in the figure of the torturer and the dramatic handling of light, which are comparable to the style of his first master in Germany, Martin Speer, author of a similar work now in the Landesmuseum, Mainz; the smooth handling of anatomy evokes the study of Pompeo Batoni's paintings; the very striking and dramatic close-up view of the half-length figure recalls Mattia Preti's handling of the same subject, especially in the version now in the Currier Gallery of Art, Manchester, New Hampshire ${ }^{3}$; but, most of all I want here to point to a model which is of great importance for our topic: the saint's pose, in fact, echoes one of the most famous antique models in Rome, the Laocoön (Vatican, Museo Pio Clementino) [1].

\footnotetext{
Explicit evidence of Zoffany's Roman relations is also provided by the dedication to him in a Piranesi's etching, mentioned in the text below.

$2 \quad$ Signed and dated 'Zauffalij inv/175 [?]', which is 1753 thanks to a comparison with a copy in Alte Kapelle, in Regensburg.

A copy is also in San Silvestro in Quirinale, in Rome.
} 
Such education will mark Zoffany as an individual and as an artist and play role when he works at his Tribuna, creating a very peculiar atmosphere and a vivid mirror of the eighteenthcentury artistic passions and of the Grand Tour.

This German artist long active in Hannoverian Britain provides further opportunities of appreciating how classical art inspired European collectors, such as in Charles Townley's Library (1781-1798, Burnley, Townley Hall Art Gallery and Museum).

Charles Townley (1737-1805) was the most famous of the many English collectors and the painting was conceived by the artist "as a labour of love, a microcosm of the enlightened antiquarian culture to which Zoffany had a deep personal attachment" [9, p. 241]. Zoffany portrayed him in his library with an imaginary assembly of the entire collection in the one room. He is shown with three friends: Charles Greville, a politician and mineral collector, Thomas Astle, an authority on ancient manuscripts and Pierre d'Hancarville, French antiquarian, scholar and art dealer.

The deep affinity between the Tribuna and Townley's Library is clear in the original commission of the second painting, on which Townley himself wrote: "Mr. Zoffani is painting, in the Style of his Florence tribune, a room in my house, wherein he introduces what Subjects he chose in my collection" [12, p. 32; 9, p. 241]. Probably Townley met Zoffany in Florence for the first time, and in Florence, or better, between Florence and Rome we can find the lively, international world of Grand Tourists, especially collectors and 'amateurs' that linked together men and destiny from Britain to Russia, as we'll see below. It surely wasn't by chance that one of the principal dealers used by Townley was the great architect and engraver Giovanni Battista Piranesi, who also dedicated one of his widespread antique inspired etchings to Zoffany: the one in the Vasi, Candelabri, Cippi series (1778) where he refers to the artist as a friend.

The Tribuna provides a perfect list of essential models, to the point of suggesting an unforgettable scene in Stanley Kubrick's 1975 movie Barry Lyndon, evoking a precise atmosphere in the Zoffany style, when Barry visits a first-rank English collection, in the real setting at Stourhead [1].

The Royal commission to Zoffany to paint the Tribuna in the Uffizi Gallery originated from its amazing reputation: King George III and especially Queen Charlotte wanted to see that famous room in Florence, wanted to discover those beauties and also learn from them in order to refine their art collecting but the only way they had, at the moment, to see the Tribuna, was to possess a painting of it.

In the end, anyway, Zoffany's canvas will be very peculiar: not a reproduction of the Tribune, but a lively 'conversation piece', populated by British travelers talking with each other passionately while admiring the marvelous works of art: almost a theatrical scene that explains the cultural value of that experience.

In addition, Zoffany mixes works of art with great freedom, selecting those that are clearly in tune with the taste of the moment, especially British taste: Raphael, Correggio, Titian, but also Annibale Carracci, Guido Reni, Rubens, the Flemish and those ancient models that were then becoming more and more the highlight of the trip to Italy.

It was especially in the second half of the $18^{\text {th }}$ century that passion for the antique revealed educated individuals in Europe. The Tribune offers some of the best known and appreciated models of this international taste: "On entering, the six famous Greek statues draw the 
attention; and it is not until after these have had a full examination, that you can attend to the pictures and other curiosities with which this room is filled" (Letter from December 1770) [7, II, p. 110; 14, p. 285].

At that time the Tribune contained six masterpieces, beloved and celebrated throughout Europe and still considered Greek originals [2, p. 196; 14, p. 285; 10, p. 140] ${ }^{4}$ : The Venus of Medici ${ }^{5}$, The Dancing Faun, The Wrestlers, The Arrotino, The Infant Hercules and The Apollino ${ }^{6}$

Zoffany also chooses to paint the outstanding bronze of the Chimera of Arezzo, discovered in 1554 and placed in a corridor of the Gallery in 1770. This was a marvelous sign of the Etruscan fashion that was then becoming more and more widespread but undoubtedly was a special passion for British collectors and scholars. It's enough to remember sir William Hamilton's great collections of Etruscan vases that conquered 'amateurs' and artists all over Europe. Pierre D'Hancarville, editor of the collection catalogue, was portrayed by Zoffany in The Townley's library.

The Academy of Cortona, one of the main centers of the Etruscan vogue, honored Zoffany the right to become one of its members in 1778 and the artist sent there a fancy Self-portrait with a Plumed Hat still in the local public collection.

With reference to the international, lively circle gathered around Zoffany in Florence when he was working at his Tribuna, from 1772 to 1777, there is now a chance of shedding new light on a less known episode which deserves greater attention.

It concerns portraits painted by Zoffany for two very important Russian grandees: the Orlovs brothers, namely Prince Grigorii Grigor'evich Orlov, Aleksei Grigor'evich Orlov-Chesmenskii (1737-1808), strictly linked to Catherine's the Great personal life and imperial destiny, since Grigorii had been Catherine's favourite for a long time until 1772 and they were both involved in the putsch of 1762 after which Aleksei is supposed to have strangled dethroned Emperor Peter III.

We know from reliable sources that Zoffany had portrayed the Orlov brothers while in Florence.

Maria Hadfield (1760-1838) [5; 14, p. 317-318], future wife of Richard Cosway and a painter herself, was a Zoffany's apprentice in Florence, and she gives us important information on his life and works. On February 24, 1776 she relates that "Mr. Zoffani has begun the portrait of the Princess Christina who is a sister of the Grand Duke, has almost finished the portraits of General and Prince Orloff, but I do not know how advanced is the large portrait [of the Family of Pietro Leopoldo] since I have not seen it for a long time"7.

See a monograph by M. Webster [14, p. 285] for historical information and sources on each statue. Zoffany omitted the other Venus in Tribuna, Victrix (with the apple of Paris) and Urania (emerging from the bath), that we can see in Pignatta's painting also in order to stress the importance of the Medici one and let her stand in evocative isolation, see [14, pp. 286-287].

The Apollino, placed in the Tribuna since 1771 doesn't appear in the painting but it's possible that Zoffany erased it and chose to paint only the Infant Hercules [14, p. 286]. The Infant Hercules strangling two serpents, one of the masterpieces of lesser size, is present here but Zoffany doesn't paint the Apollino. The only ancient statue not really placed in the Tribuna at time is the Cupid and Psyche group, visible at far left in the painting, probably much admired by Zoffany himself. Running round the walls of the Tribuna we see a selection of small ancient sculptures in marble, bronze, hardstone on shelves.

$7 \quad$ London, Royal Academy, HU, II, 42. Quoted in a monograph by M. Webster [14, p. 318]. It's a group of letters to the miniature painter Ozias Humphry (1743-1810), who she had met in Florence. 
Aside two well-known Zoffany's paintings are mentioned here - Archduchess Maria Cristina (1776), and The Family of the Grand Duke Pietro Leopoldo (1776), both in Vienna, Kunsthistorisches Museum. Maria reveals us that Zoffany "has almost finished" "the Portraits of General and Prince Orloff”, namely Prince Grigorii and Count Aleksei Orlov.

The Orlov brothers were probably introduced to Zoffany by sir John Dick, who is recognizable among the travelers in the Tribuna: he is just aside the British regent in Florence and enthusiastic patron of Zoffany, George Nassau, third Earl of Cowper, while admiring Raffaello Niccolini-Cowper Madonna, the Great Madonna Cowper, nowadays at Washington, National Gallery of Art, sold around 1773 by Zoffany to Cowper: the only painting not in property of the ducal collections - what a coincidence! We can notice that Sir Dick wears the insignia of the Imperial Order of St. Anne of Schleswig-Holstein, granted to him for his services to the Russian fleet at Leghorn by Catherine the Great and delivered to him by Count Orlov himself at Pisa on February 28, $1775[4, \text { p. 319-324] }]^{8}$.

Towards 1775 the two brothers found themselves in Florence after many vicissitudes and wanderings. Aleksei, the hero who had defeated the Turks at Chesme in 1770 - he was granted the honorific Chesmenskii - and for a period conquered the Greek archipelago. After the peace of 1774 he went back with the Russian fleet in Leghorn, where Sir John Dick was in charge of administering their powerful accounts. In the meantime, also Grigorii reached Florence after he had travelled around Europe for some years [13, p. 92, 113-114, $143 ; 14$, p. 318 $]^{9}$.

In any case, we know that Zoffany portrayed them, and that around spring 1776 he finished the commission. More difficult is to clarify from our source if he painted one or two paintings and if the brothers were painted together or separately.

We know derivations from the originals [14, p. 318-320, 665, fn. 67], and they are undoubtedly very precious to reconstruct the whole story, to which we can here add something new, in order to arise the hope to track down Zoffany's portraits one day, may be in Russia.

Derivations and adaptations from Zoffany's original or originals we can now recognize in two small twin-portraits (Moscow, State Historical Museum; Saint Petersburg, now private collection) attributed to a French painter, long living in Russia, Jean Louis de Veilly (17441805). Both of them have signs of the hero's life and personal story on the background: Prince Grigorii, on the right of both paintings, points to a riot he had quelled in Moscow. Count Aleksei in the Moscow painting points with his admiral's baton at the fleet in a distance, evoking Chesme battle, while in the other hand "he holds a cane in front of a console table" where is posed his brother's "hat, books and red ermine-bordered drapery" [14, p. 319] ${ }^{10}$.

\footnotetext{
$8 \quad$ In Spring 1775, Dick was accused of being Aleksei Orlov's accomplice in the capture of a young Russian woman who claimed to be a daughter of the Empress Elizaveta Petrovna. This "Princess Yelizaveta Tarakànova", was imprisoned, chained and sent to Russia, with a trap, much to the disappointment of the Grand Duke Peter Leopold, see [14, p. 319].

$9 \quad$ We also know that on June 27, 1775, Horace Mann reported to Horace Walpole that: "The Prince and his brother, Count Orlov, have often been here of late" but that the Prince had now gone to Spa to take the waters. From there he went to England in September". Here we learn that Zoffany was thought to be going to Russia, Letter from June 27, 1775, [13, p. 92, 113-114, 143, also quoted in 14, p. 318].

10 Mary Webster [14, p. 319] reproduces the portrait as the one from the Moscow State Historical Museum, though in fact the described portrait is the one from Saint Petersburg (private collection).
} 
Under the table, on the left of the Moscow painting, one can also notice a little sculpture with a winged Cupid, his arms wide opened, his right hand seems to touch something put on a lion's paw, something similar to a 'trapezoforo' for a 'trapeza'. This is a known iconography and a cameo is in Florentine collection. Note also the medallion above the Cupid, as a little 'oscillum'. It's hard to say more without checking the painting directly but this last detail is undoubtedly another confirmation of the antique taste of the Orlovs, mostly appreciated while in Florence.

In both paintings the Russian brothers appear together in the same canvas, which could be a trace of the original composition. We must specify, nevertheless, that we can't be sure of this. The different background behind Count Aleksei in the two paintings suggests creative variations on the basis of several originals. We have similar examples in Zoffany's catalogue, such as the Portraits of the Bourbons of Parma (Parma, Galleria Nazionale), and it's not unlikely that such important noblemen had large-scale individual portraits [14, p. 319].

In any case, the best proof that the Orlovs' portraits come from an original by Zoffany is a beautiful painting in Tretyakov Gallery, Moscow (Ill. 113), in which you can see Count Aleksei's half-length portrait hanging on the wall - the one clearly based on the same wholelength original as the aforementioned copies.

This is a final confirmation, not only as a document of a derivation [14, p. 319], from an original by Zoffany but very more than this, according to my opinion, being the Tretyakov portrait an original Zoffany, most probably executed in Florence when the artist worked at the Orlovs portrait, 1776.

The picture represents an elegant seated woman embroidering with her black servant holding a cage with a canary. On the wall behind her there is Count Aleksei's portrait, in which he is depicted wearing the uniform of an admiral and pointing to the battle of Chesme ${ }^{11}$ : this is a traditional family iconography, as I'll demonstrate below, especially widespread in representing a couple, where the wife is portrayed with a painting in the room evoking her husband.

Therefore, even if we unfortunately can't be sure at the moment, of the sitter's identity ${ }^{12}$, she must be closely related to count Aleksei (his wife or fiancée), as also the canary in the cage suggests ${ }^{13}$. Aleksei's unlucky wife, Evdokiia Nikolaevna died very young, in 1786, aged only 25, giving birth to their son Ivan; a girl, Anna was born in 1785. Evdokiia and Aleksei had married in 1782, when Zoffany had already been in London for three years and almost leaving for India as the aforementioned copies (Ill. 113).

11 It probably conveys an episode during the battle, when Orlov caused a terrible burning, having hit a Turkish ship carrying gunpowder [14, p. 319].

12 I am very grateful to Natalia Presnova from the State Tretyakov Gallery, for the detailed and precious information on the painting. The painting in the Gallery's entry is entitled Portrait of unknown woman with embroidery and negro serving, dated around 1770 and attributed to Unknown foreign artist of the 2nd half of the 18th c. Inv. 4874, oil on canvas, $75,5 \times 63,5 \mathrm{~cm}$. As the aforementioned Orlovs portraits' copies, it had a traditional attribution to the French painter Jean Louis de Veilly.

13 It is unlike, by this reason, the identification of the model with S.A. Craig, admiral's S.K. Craig wife, proposed by G.B. Andreeva, who rightly supposed that the canvas is stylistically close to Zoffany's manner, especially while in Florence. The Craigs were friends of count Orlov and they were in Italy when he was there. In addition, lady Craig was a cousin of the famous mariner James Cook, with whom Zoffany was intended to leave for the round-the-world journey just before coming to Florence. It is therefore very likely that the Craigs could contribute to introduce count Orlov to Zoffany but the model of a portrait like this could only be a woman in intimate connection with count Aleksei. 
The comparison with Eudokia's known images doesn't help us but we can certainly say that the sitter hardly seems to be as young as Eudokia would have been in those years ${ }^{14}$, around 1776 , perfectly compatible with the style of the picture, such as with fashion of the time. It is possible that the model could be the count Aleksei's beloved Ekaterina Zherebtsova Demidova (born in 1748 and therefore quite older around 1776-78) ${ }^{15}$. The solution of the sitter's ambiguity will help to understand the whole story of the painting and its author. Zoffany was in Florence till spring 1778 when he left for Parma where he stayed about one year before going back to London. We know he executed the Orlovs' portraits in 1776, and they should have appreciated Zoffany's work so much that some sources say he was supposed to go to Russia [13, p. 92, 113-114, 143; 14, p. 318; see also fn. 10].

Anyway, the painting is undoubtedly in Zoffany's manner when he was in Italy, between 1772 and 1779.We see this in every detail, such as textile materials, light, composition and in particular - the special choice made for the background, where we can see sunset light, the one preferred by Zoffany, especially while in Florence and Parma [1]. Here, a glance falls on a landscape from a bower wine-trellis - very Italian indeed - backlit by the evening light, and thus shadowed in the foreground. Zoffany favoured this stylization in other similar works of the same period, such as the Portrait of George Nassau, Third Count Cowper (1773, Firle Estate Settlement) or the portrait of his betrothed, Miss Ann Gore as a Savoyard (1774, Firle Estate Settlement), and again in The Portrait of Lord Cowper and the Gore Family (1774-75, New Haven, Yale Center for British Art, Paul Mellon collection), The Portrait of the Archduchess Maria Christina (1776, Vienne, Kunsthistorisches Museum), The Portrait of Matilda Cleveland (1777, private collection), Mrs Peachum reproaching her daughter Polly (1777-78, private collection). You always find landscape and buildings shadowed in the foreground: the Tretyakov gallery picture shows a particularly convincing comparison with a masterpiece of the time in Parma, in which you find the same stylization - I refer to The Four Grandchildren of Maria Teresa (1778, Vienna, Kunsthistorisches Museum) where even the architectural proportions greatly recall those used in the portrait now in question [1]. Here I show it as a comparison that doesn't need to be expounded (Ill. 114).

The Tretyakov gallery portrait reveals very high quality in every detail and it absolutely can't be a copy. More than this, it contains, as said, all the details of Zoffany's style, including personal notes such as the typical orange in the woman's dress, around her neck, the sitter's face and glance, the hand and gesture, the peculiar way of distributing objects in space, sometimes without any care in perspective vision.

We can also add an ultimate evidence that Zoffany executed this kind of composition. As a matter of fact there is a painting very similar to this one and very close to Zoffany's style: it went up recently for auction at Sotheby's, London, July 3, 2013, lot. 43, and represents Arch-

14 We have the same problem if we accept the identification with E.N. Orlova Zinovieva (1758-1781), besides the fact that she was the wife of prince Grigorii Orlov and it makes nonsense she was here reproduced with the portrait of her brother-in-law.

15 This identification is due to T.V. Alekseeva, quoted by G.B. Andreeva, as Natalia Presnova informed me and as registered in the entry of the painting in Moscow Gallery. M. Webster reproduces the Tretyakov portrait as a Portrait of Maria Bachmetieva [14, p. 319, dated around 1780] by Anonymous, which is an unlike identification, considering that Maria was the woman who lived with count Aleksei after she had parted her husband at the end of 1780 s - early 1790 s and she was the youngest of the women here mentioned, being born in 1766. 
duchess Maria Amalia of Austria, Duchess of Parma. Behind her, on the wall, we see a portrait of her husband, Ferdinand of Bourbon, coming from the original portrait by Zoffany, unfortunately lost, like the one of his wife.

It is remarkable, by this reason, that the portrait in the Sotheby's picture reflects exactly the lost original by Zoffany, as we can see it in the engraving by S. F. Ravenet, where the Duke wears a blue band [6, p. 80-83], - the only engraving compatible with the years when the artist was in Parma, 1778. We are therefore certain, if bad quality of the portraits wasn't enough to prove it, that the two portraits of the couple in the National Gallery in Parma are copies $[3$, p. 89, n. 79].

Here you see Ferdinando wearing decorations - white band with lateral light blue bands, combined with the big Cross of the Immaculate - incompatible with Zoffany's in Parma, between 1778 and 1779, being the result of a transformation occurred after 1792 [6, p. 80]. Before 1792, the band was light blue with thin white lateral edges, as shown in the coloured engraving by Ravenet, now in a French private collection $\left[6\right.$, p. 83; 11, p. 287 ${ }^{16}$. In any case, the success of these models was enormous. Copies of both Ferdinando's and Maria Amalia's portraits are widespread [14, p. 666, note 12] and provide further evidence of Zoffany's prototypes fame. They all are, exactly like the Orlovs' portraits, very distinguishing signals of the value of his artistic heritage.

This reconstruction opens up a really interesting view on contemporary continental artmarket and the cultural exchanges, of which the Tribuna by Zoffany is the best report as well as his portraits of famous and important European travelers and grandees like the Orlov brothers. I hope, finally, that it also might help to retrieve the original Orlovs' portraits, which probably hang still unacknowledged somewhere in Russia ${ }^{17}$.

Title. Johann Zoffany, Classical Art, Italy and Russian Patronage: Shedding New Light on Models, Men and Paintings.

Author. Anna Maria Ambrosini Massari - Professor. The Carlo Bo University of Urbino, Via Bramante 17, 61029 Urbino, Italy. anna.ambrosinimassari@uniurb.it

Abstract. Johann Zoffany's famous painting of the Tribuna of the Uffizi (Royal Collections, UK) does not portray that room as it was, but sums up a number of classical models of paramount importance in the artistic and social education of any well-bred person in eighteenth-century Europe.

This German artist, long active in Hannoverian Britain, provides opportunities of appreciating how classical art inspired European collectors, such as in Charles Townley's Library (Burnley, Townley Hall Art Gallery and Museum). Nevertheless, the Tribuna undoubtedly provides a perfect list of essential models with a reference to the international, lively circle gathered around Zoffany in Florence when he was working at his Tribuna, from 1773 to 1777. The paper sheds new light on a less known episode which deserves greater attention. It concerns the portraits painted by Zoffany for two very important Russian grandees: the Orlov brothers, namely Prince Grigorii, who had been Catherine the Great's favourite, and Count Aleksei. It was most probably through one of the Orlovs that the Empress heard of the Tribuna, a painting that according to some sources she tried to obtain for her prominent collection at the Hermitage. Zoffany's portraits of the Orlovs are as yet untraced, but the paper offers reconstruction of their complete story based on notable written sources, some copies and derivations and other connected works. This reconstruction opens up the author's view on contemporary continental art-market and the cultural exchanges between Italy and Russia, with special focus on classical art. It might also help to retrieve the original portraits of the Orlovs, which probably hang still unacknowledged somewhere in Russia.

Keywords: Zoffany; Classical art; Italy art; Britain; Russia.

16 This information was due to Davide Gasparotto, who published this painting with some reservations as Zoffany. See also a monograph by P. Treadwell [11, p. 287], who mentions a similar portrait up for auction in New York in 1998, indicated to her by Brian Allen e Guy Sainty. Was this the same picture?

17 The "English Chronicle" of September 10-12, 1789 informs that even the Tribuna could have gone to Russia, if the artist had accepted the high offer of the Empress, a passionate collector, to whom, most likely, the Orlov brothers themselves praised the picture. 
Название статьи. Живопись Иоганна Цоффани, античное искусство, Италия и русские покровители: новый взгляд.

Сведения об авторе. Анна Мария Амброзини Массари - профессор. Урбинский Университет имени Карло Бо, Via Bramante 17, Урбино, Италия, 61029. anna.ambrosinimassari@uniurb.it

Аннотация. Помещение, изображенное на знаменитой картине Иоганна Цоффани «Трибуна Уффици» (Королевское собрание, Виндзорский замок, Великобритания), не дает представления о подлинном облике зала, однако на полотне показаны произведения искусства, самые значимые и в художественном отношении, и с точки зрения образованности, которые подобало знать каждому хорошо воспитанному и просвещенному европейцу.

В творчестве И. Цоффани - немецкого художника, долгое время работавшего в Ганноверской Британии, содержится достаточно указаний на то, как европейские коллекционеры вдохновлялись античным искусством, например в картине «Библиотека Чарльза Таунли» (Бэрнли, Художественная галерея и музей в Таунли Холл). Кроме того, в картине «Трибуна Уффици» безупречно подобран состав памятников и показан обобщенный портрет того живого интернационального окружения, в котором художник вращался во Флоренции с 1773 по 1777 г., во время работы над «Трибуной». В статье предлагается авторское видение одного малоизвестного эпизода того времени, заслуживающего отдельного внимания. Речь идет о написанных Цоффани живописных портретах двух весьма влиятельных русских вельмож: светлейшего князя Григория Орлова, фаворита Екатерины II, и его брата графа Алексея Орлова. Возможно, именно от одного из братьев императрица узнала о создании полотна «Трибуна Уффици», которое, согласно некоторым источникам, она пожелала приобрести для своего блистательного собрания в Эрмитаже. Следы портретов братьев Орловых кисти Цоффани теряются, однако автор статьи, опираясь на важные письменные свидетельства, делает попытку полностью реконструировать историю их создания, выявить копии, варианты и некоторые другие связанные с ними произведения. Предложенная реконструкция способствует лучшему пониманию характера европейского художественного рынка и культурного обмена между Италией и Россией, причем особое внимание уделяется произведениям античного искусства. Эта работа, по мнению автора, может способствовать обнаружению оригинальных портретов братьев Орловых, которые, как он полагает, могут, оставаясь не атрибутированными, находиться где-либо в России.

Ключевые слова: Иоганн Цоффани; античное искусство; искусство Италии; Великобритания; Россия.

\section{References}

1. Ambrosini Massari A. M. Johan Zoffany in Italy: “...così esattamente che più oltre non si potrebbe”. Hogarth, Reynolds, Turner. British painting and the rise of modernity: Exhibition Catalogue. Milan, Skira Publ., p. 117-123 (in Italian).

2. Bianchi G. Ragguaglio Delle Antichità E Rarità Che Si Conservano Nella Galleria Mediceo-Imperiale Di Firenze. Firenze, Stamperia Imperiale Publ., 1759. 236 p. (in Italian).

3. Campbell Orr C. Six Courts and Four Empires: Zoffany as Courtier. Johan Zoffany RA: Society Observed: Exhibition Catalogue. New Haven - London, Yale Center for British Art, Yale University Press Publ., pp. 74-99.

4. Carlisle N. A concise account of the several foreign orders of the knighthood, and other marks of honourable distinction, especially of such as have been conferred upon British subjects: together with the names and achievements of those gallant men, who have been presented with honorary swords, or plate, by the Patriotic Fund Institution. London, J. Hearne Publ., 1839. 582 p.

5. Gipponi T. Maria Headfield Cosway: il fascino di una donna colta, geniale e moderna. Maria e Richard Cosway. Torino, Umberto Allemandi Publ., 1998, pp. 11-36 (in Italian).

6. Giusto M. Principi in posa. Ritratti del Settecento alla Galleria Nazionale di Parma. Nuove acquisizioni e restauri: exhibition catalogue. Parma, Silvana editore Cinisello Balsamo Publ., 2005. 95 p. (in Italian).

7. Miller Lady A. Letters from Italy, describing the manners, customs, antiquities, paintings, \& c. of that country, in the years MDCCLXX and MDCCLXXI, to a friend residing in France. By an English woman, vol. 2. London, Edward and Charles Dilly Publ., 1776, 434 p.

8. Postle M. Johan Zoffany: An Artist Abroad. Johan Zoffany RA: Society Observed: Exhibition Catalogue. New Haven - London, Yale University Press Publ., 2012, pp. 13-49.

9. Postle M. Johan Zoffany: RA Society Observed: Exhibition Catalogue. New Haven — London, Yale Center for British Art, Yale University Press Publ., 2012, pp. 241-242.

10. Shawe-Taylor D. The Conversation Piece: Scenes of Fashionable Life: Exhibition Catalogue. London, Royal Collection publications Publ., 2009. 192 p.

11. Treadwell P. Johan Zoffany Artist and Adventurer. London, Paul Holberton Publ., 2009. 469 p.

12. Vaughan G. Reflections on Charles Townley and His Friends. Apollo, 1996, no. 144, p. 32-35.

13. Walpole H. Horace Walpole's Correspondence with Sir Horace Mann. The Yale Editions of Horace Walpole's Correspondence, vol. 24. New Haven, Yale University Press Publ. — London, Oxford University Press Publ., 1967. 553 p.

14. Webster M. Johan Zoffany. New Haven — London, Yale University Press Publ., 2011. 708 p. 